\title{
Lårhalsbrudd og kroppshøyde
}

\author{
Haakon E. Meyer \\ Forskningsavdelingen, Statens helseundersøkelser, Pb. 8155 Dep, 0033 Oslo \\ Tlf: 22207655 Fax: 22201673 E-post: haameyer@online.no
}

\begin{abstract}
SAMMENDRAG
De aller fleste lårhalsbrudd skjer i forbindelse med fall, og de senere år er det blitt mer og mer klart at forhold knyttet til falltraumet er av stor betydning for risikoen for å få lårhalsbrudd. I denne sammenheng har kroppshøyde vakt interesse pga. større fallhøyde og lengre lårhals hos høye personer. Vi har tidligere vist en klar sammenheng mellom kroppshøyde og risiko for lårhalsbrudd. Spørsmålet er om kroppshøyden kan være med å forklare de observerte forskjellene og forandringene i insidensen av lårhalsbrudd. Data fra Bergen, Nord-Trøndelag og Møre og Romsdal innsamlet i perioden 1963-70 og 1989-93 viser en klar økning i høyden hos to generasjoner 65-67 åringer. Høyden økte i gjennomsnitt med 3,8 cm hos menn og med 3,1 cm hos kvinner. Estimat bygd på gitte forutsetninger viser at dersom høyden i den norske befolkningen hadde blitt redusert tilsvarende, ville antall lårhalsbrudd blitt redusert med 15,7\% (anslagsvis 1338 lårhalsbrudd per år). Tilsvarende beregninger viser at dersom gjennomsnittshøyden hos nordmenn ble redusert til sydeuropeiske nivå, ville en ha forventet 26,8\% færre brudd (reduksjon på anslagsvis 2279 lårhalsbrudd per år). Høyde synes således å være en av faktorene som forklarer den økende insidensen av lårhalsbrudd i den norske befolkningen og de høye bruddratene sammenlignet med andre land.
\end{abstract}

Meyer HE. Hip fracture and body height. Nor J Epidemiol 1997; 7 (2): 175-178.

\section{ENGLISH SUMMARY}

Most hip fractures occur following a fall. During recent years it has become evident that factors associated with falling and trauma following a fall are of great importance in the etiology of hip fracture. In this connection, tall persons may have an increased risk of hip fracture due to geometric features of the hip (longer femoral neck), and greater forces associated with falling. We have previously reported a clear association between body height and the risk of hip fracture. The question is if the observed differences and changes in the incidence of hip fracture can be attributed to body height. Data from three Norwegian counties collected during 1963-70 and 1989-93 showed that height increased by $3.8 \mathrm{~cm}$ in men and $3.1 \mathrm{~cm}$ in women in two successive generations of persons 65-67 years old examined 24 years apart. It is estimated, under certain assumptions, that if body height in Norwegians was reduced correspondingly $(3.8 \mathrm{~cm}$ in men and $3.1 \mathrm{~cm}$ in women), we would have expected a reduction in the number of hip fracture by $15.7 \%$ or 1338 hip fractures per year. Similarly, if body height in Norwegians was reduced to Southern European levels, we would have expected a reduction of $26.8 \%$ or 2279 hip fractures per year. In sum, height is probably one of several factors contributing to both the secular increase and geographical differences in the incidence of hip fracture.

\section{INNLEDNING}

En rekke faktorer har innvirkning på forekomsten av lårhalsbrudd (1). Av stor betydning er osteoporose og faktorer knyttet til utviklingen av denne, slik som økende alder, det å være kvinne, mager kroppsbygning, dårlig kosthold, røyking, fysisk inaktivitet osv. Imidlertid skjer de aller fleste lårhalsbrudd $\mathrm{i}$ forbindelse med fall, og de senere år er det blitt mer og mer klart at forhold knyttet til falltraumet er av stor betydning for risikoen for å få lårhalsbrudd. Dette innbefatter bl.a. glatt underlag, dårlig belysning, fallhøyde, økt falltendens hos den enkelte, dårlig evne til å ta seg for ved fall og fall direkte mot hoften. Ikke minst synes lokale forhold som mengde bløtvev som polstrer hoften samt geometrisk forhold i selve lårhalsen å være av stor betydning for om et fall fører til brudd eller ikke.

I denne sammenheng har kroppshøyde vakt interesse. For det første vil en høy person ha større fallhøyde ved fall fra oppreist stilling. Biomekaniske beregninger kan tyde på at $9 \mathrm{~cm}$ økning i fallhøyde øker risikoen for brudd med omkring 50\% (2). Videre vil høye personer i gjennomsnitt ha lengre lårhals, og lang lårhals gir økt risiko for brudd (3). Økende høyde er 
imidlertid ikke en risikofaktor for osteoporose. Det er tvert imot en svak, positiv sammenheng mellom kroppshøyde og beinmasse (4).

\section{HØYDE OG LÅRHALSBRUDD}

Vi undersøkte sammenhengen mellom lårhalsbrudd og kroppshøyde blant personer som møtte til første runde av hjerte-karundersøkelsene utført av Statens helseundersøkelser i Finnmark, Sogn og Fjordane og Oppland i perioden 1974-78. Omkring 50000 menn og kvinner i alderen 35-49 år deltok i undersøkelsen som bl.a. omfattet måling av høyde og vekt. Vi fulgte denne kohorten og registrerte hvem som ble innlagt med lårhalsbrudd på sykehusene i de tre fylkene til og med 1990. I de påfølgende analyser (5) fant vi en klar sammenheng mellom økende kroppshøyde og risiko for lårhalsbrudd (figur 1). Det viste seg bl.a. at de høyeste mennene hadde en høyere insidens av lårhalsbrudd enn de laveste kvinnene. Omregnet til relativ risiko fant vi at $10 \mathrm{~cm}$ høydeøkning gav en risikoøkning på 58\% hos kvinner og $119 \%$ hos menn. Dette har senere blitt bekreftet i en stor amerikansk osteoporosestudie hvor $10 \mathrm{~cm}$ økning av høyden (selvoppgitt høyde ved 25 års alderen) gav 55\% økt risiko for lårhalsbrudd hos eldre kvinner (6). Også andre studier har bekreftet sammenhengen mellom høyde og lårhalsbrudd $(7,8)$.

Norge og de andre skandinaviske land ligger på verdenstoppen i lårhalsbruddhyppighet, og hyppigheten (insidensen) av lårhalsbrudd har økt over tid (1). Spørsmålet er om forskjeller og forandringer i kroppshøyde kan være en medvirkende årsak til dette.

\section{HØYDEØKNING OVER TID}

Det er kjent at høyden til vernepliktige norske menn har økt med bortimot $10 \mathrm{~cm}$ i løpet av dette århundret (9), dette trolig pga. bedre ernæring/levevilkår i oppveksten. Vi har sammenlignet høyden hos to gene-
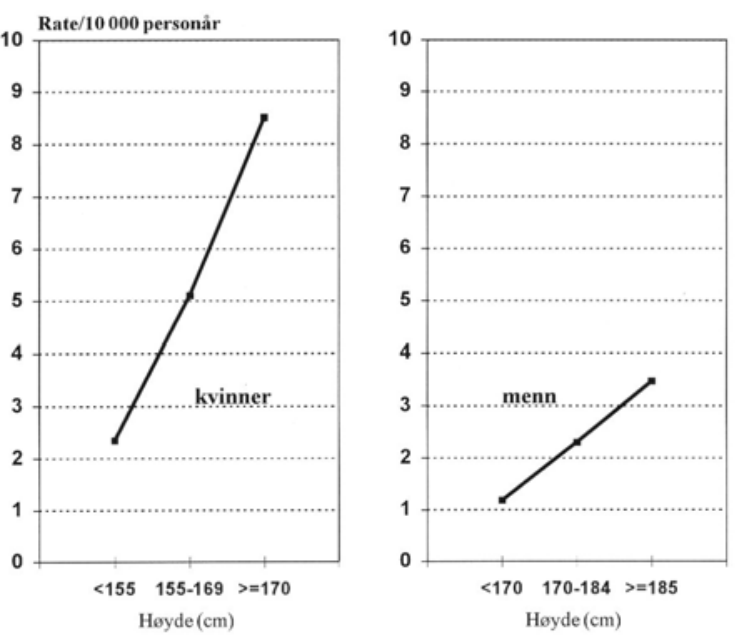

Figur 1. Insidens av lårhalsbrudd $\mathrm{i}$ henhold til høyde. Kvinner og menn i tre norske fylker. rasjoner 65-67 åringer i tre norske fylker. Den første generasjonen ble undersøkt $\mathrm{i}$ forbindelse med den landsomfattende tuberkulosescreeningen utført av Statens helseundersøkelser (Statens skjermbildefotografering) i Bergen (1963-64), som den gang var eget fylke, Nord-Trøndelag (1966-69) og Møre og Romsdal (1966-70). Den andre generasjonen ble undersøkt ved hjerte-karundersøkelsene i Nord-Trøndelag (1989), Møre og Romsdal (1990) og Hordaland (1992-93). For Hordaland sitt vedkommende er kun personer fra Bergen tatt med. Tilsvarende analyse ble gjort for aldersgruppen 40-42 år.

I alle de tre fylkene var det en klar økning i høyden fra 1. til 2. generasjon 65-67 åringer (tabell 1), og tilsvarende funn ble gjort for aldersgruppen 40-42 år (tabell 2). I gjennomsnitt var det ca. 24 år mellom undersøkelsene. Ved å slå sammen data fra de tre fylkene fant vi som gjennomsnittstall at kroppshøyden økte med bortimot $4 \mathrm{~cm}$ hos menn og i overkant av 3 cm hos kvinner for aldersgruppen 65-67 år (tabell 3). Tilsvarende tall for aldersgruppen 40-42 år viste en økning på omkring $3 \mathrm{~cm}$ hos begge kjønn, dvs. at også framtidens eldre vil være høyere enn de foregående generasjoner eldre.

\section{HØYDE OG GEOGRAFI}

I forbindelse med en europeisk multisenterundersøkelse (European Vertebral Osteoporosis Study (10)), hvor Oslo deltok sammen med 35 andre senter i 19 europeiske land, ble det bl.a. registrert høyde og vekt på ca. 17000 menn og kvinner i aldersgruppen 50-79 år. Ved å benytte data fra denne undersøkelsen fant vi at menn og kvinner i Oslo var betydelig høyere enn både vesteuropeere, øst-europeere og syd-europeere (figur 2) (11). Menn i Oslo var således i gjennomsnitt 8,6 cm høyere enn syd-europeiske menn, og tilsvarende var Oslo-kvinnene 5,2 cm høyere.

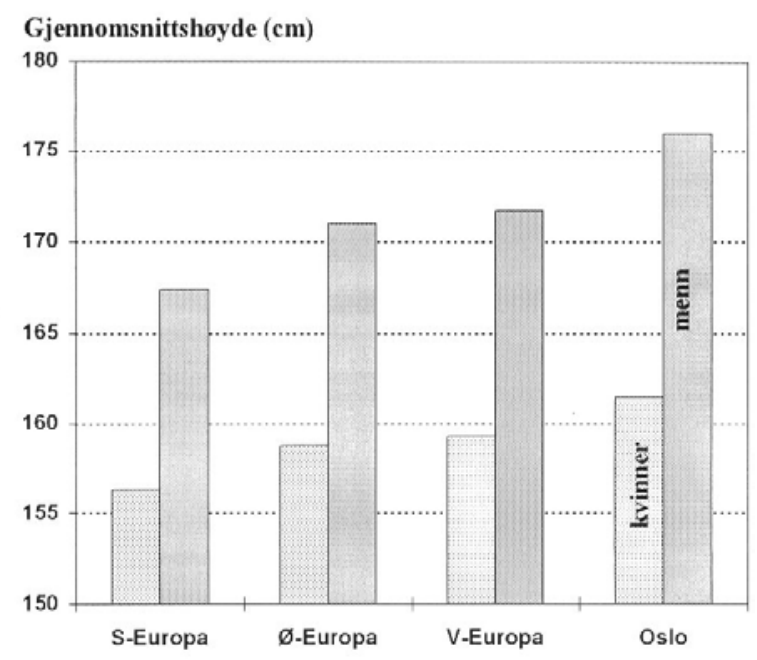

Figur 2. Gjennomsnittshøyde hos menn og kvinner 50-79 år gamle som deltok i multisenterundersøkelsen European Vertebral Osteoporosis Study. 
Tabell 1. Gjennomsnittlig kroppshøyde $(\mathrm{cm})$ hos to generasjoner norske menn og kvinner i aldersgruppen 65-67 år i tre norske fylker.

\begin{tabular}{|c|c|c|c|c|c|c|c|c|c|c|c|c|}
\hline \multirow[b]{3}{*}{ Undersøkelsesår } & \multicolumn{4}{|c|}{ Bergen } & \multicolumn{4}{|c|}{ Nord-Trøndelag } & \multicolumn{4}{|c|}{ Møre og Romsdal } \\
\hline & \multicolumn{2}{|c|}{ menn } & \multicolumn{2}{|c|}{ kvinner } & \multicolumn{2}{|c|}{ menn } & \multicolumn{2}{|c|}{ kvinner } & \multicolumn{2}{|c|}{ menn } & \multicolumn{2}{|c|}{ kvinner } \\
\hline & antall & høyde & antall & høyde & antall & høyde & antall & høyde & antall & høyde & antall & høyde \\
\hline $1963-64$ & 1163 & 170,7 & 1794 & 158,0 & & & & & & & & \\
\hline $1966-69$ & & & & & 1282 & 171,1 & 1397 & 158,5 & & & & \\
\hline $1966-70$ & & & & & & & & & 2146 & 171,0 & 2393 & 158,4 \\
\hline 1989 & & & & & 1638 & 173,7 & 1698 & 160,8 & & & & \\
\hline 1990 & & & & & & & & & 2541 & 174,8 & 2845 & 161,5 \\
\hline $1992-93$ & 1815 & 175,5 & 2315 & 161,8 & & & & & & & & \\
\hline Høydeøkning (cm) & & 4,8 & & 3,8 & & 2,6 & & 2,3 & & 3,8 & & 3,1 \\
\hline Økning pr. år $(\mathrm{cm})$ & & 0,17 & & 0,13 & & 0,12 & & 0,11 & & 0,17 & & 0,14 \\
\hline
\end{tabular}

Tabell 2. Gjennomsnittlig kroppshøyde $(\mathrm{cm})$ hos to generasjoner norske menn og kvinner i aldersgruppen 40-42 år i tre norske fylker.

\begin{tabular}{|c|c|c|c|c|c|c|c|c|c|c|c|c|}
\hline \multirow[b]{3}{*}{ Undersøkelsesår } & \multicolumn{4}{|c|}{ Bergen } & \multicolumn{4}{|c|}{ Nord-Trøndelag } & \multicolumn{4}{|c|}{ Møre og Romsdal } \\
\hline & \multicolumn{2}{|c|}{ menn } & \multicolumn{2}{|c|}{ kvinner } & \multicolumn{2}{|c|}{ menn } & \multicolumn{2}{|c|}{ kvinner } & \multicolumn{2}{|c|}{ menn } & \multicolumn{2}{|c|}{ kvinner } \\
\hline & antall & høyde & antall & høyde & antall & høyde & antall & høyde & antall & høyde & antall & høyde \\
\hline $1963-64$ & 1531 & 175,7 & 2002 & 162,4 & & & & & & & & \\
\hline $1966-69$ & & & & & 1692 & 175,2 & 1769 & 162,4 & & & & \\
\hline $1966-70$ & & & & & & & & & 2943 & 176,3 & 3315 & 163,2 \\
\hline 1989 & & & & & 2174 & 178,4 & 2150 & 165,6 & & & & \\
\hline 1990 & & & & & & & & & 3693 & 178,6 & 3931 & 165,9 \\
\hline $1992-93$ & 2768 & 179,1 & 3068 & 165,8 & & & & & & & & \\
\hline Høydeøkning $(\mathrm{cm})$ & & 3,4 & & 3,4 & & 3,2 & & 3,2 & & 2,3 & & 2,7 \\
\hline Økning pr. år $(\mathrm{cm})$ & & 0,12 & & 0,12 & & 0,15 & & 0,15 & & 0,11 & & 0,12 \\
\hline
\end{tabular}

Tabell 3. Gjennomsnittlig kroppshøyde $(\mathrm{cm})$ hos to generasjoner norske menn og kvinner i tre fylker målt i gjennomsnitt med ca. 24 års mellomrom.

\begin{tabular}{lrrrrrr}
\hline & \multicolumn{2}{c}{$65-67$ år } & & \multicolumn{2}{c}{$40-42$ år } \\
\cline { 2 - 3 } \cline { 6 - 7 } & menn & kvinner & & menn & kvinner \\
\hline 1. generasjon (1963-70) & 170,9 & 158,3 & & 175,7 & 162,7 \\
2. generasjon (1989-93) & 174,7 & 161,4 & & 178,7 & 165,8 \\
\hline Høydeøkning (cm) & 3,8 & 3,1 & & 3,0 & 3,1 \\
\hline
\end{tabular}

\section{ESTIMERTE KONSEKVENSER FOR ANTALL LÅRHALSBRUDD}

Vi har altså data som viser at norske kvinner og menn har blitt høyere og at nordmenn er blant de høyeste $i$ Europa. Spørsmålet er så hvor mange lårhalsbrudd som kan tilskrives disse forandringene og forskjellene. Det eksakte antall nye lårhalsbrudd per år i Norge er ukjent, men vi regner med at det ligger et sted mellom
8-9000 (12). Omkring 80\% av disse bruddene forekommer hos kvinner. I de følgende beregninger er følgende forutsetninger tatt: a) Antall lårhalsbrudd i Norge er 8500 per år. b) Risikoen for lårhalsbrudd øker med økende høyde som angitt over (5), dvs. med $58 \%$ hos kvinner og $119 \%$ hos menn per $10 \mathrm{~cm}$. Dersom høyden ble redusert med $3,8 \mathrm{~cm}$ hos menn og $3,1 \mathrm{~cm}$ hos kvinner (som vi fant over 24 års perioden), ville vi ha forventet at antall brudd ville ha blitt 
redusert med 15,7\% (dvs. en reduksjon på 1338 lårhalsbrudd per år). Tilsvarende, dersom gjennomsnittshøyden hos nordmenn ble redusert til sydeuropeisk nivå, ville vi ha forventet $26,8 \%$ færre brudd (reduksjon på 2279 lårhalsbrudd). Dette synes imidlertid kun å forklare en begrenset del av de store geografiske forskjellene. Lårhalsbruddinsidensen i Oslo er nemlig omkring 4 ganger høyere enn i Syd-Europa (11). Hvor stor del av økningen i antall lårhalsbrudd i Norge som kan tilskrives høydeøkningen er vanskelig å anslå da vi mangler gode historiske insidens-data. Imidlertid økte den aldersjusterte insidensen av lårhalsbrudd i Oslo fra 1978/79 til 1988/89 med 18\% (13). Dersom høydeforandringer skulle forklare hele denne økningen måtte kvinner på denne tiårsperioden ha økt gjennomsnittshøyden med over $3 \mathrm{~cm}$, noe som klart overgår det en vil forvente ut fra resultatene presentert over.

\section{KONKLUSJON}

Kroppshøyde synes å forklare en del av den økende hyppigheten av lårhalsbrudd $\mathrm{i}$ den norske befolkningen og deler av de høye bruddratene sammenlignet med andre land. Også framtidens eldre vil være høyere enn de foregående generasjoner eldre, noe som igjen vil ha innvirkning på forekomsten av lårhalsbrudd.

\section{REFERANSER}

1. Meyer HE. Risk factors for hip fracture - Epidemiological studies in middle-aged and old Norwegian women and men - Thesis. Oslo: National Health Screening Service, 1996.

2. Hayes WC, Myers ER, Morris JN, Gerhart TN, Yett HS, Lipsitz LA. Impact near the hip dominates fracture risk in elderly nursing home residents who fall. Calcif Tissue Int 1993; 52: 192-8.

3. Faulkner KG, Cummings SR, Black D, Palermo L, Gluer CC, Genant HK. Simple measurement of femoral geometry predicts hip fracture: the study of osteoporotic fractures. J Bone Miner Res 1993; 8: 1211-7.

4. Edelstein SL, Barrett-Connor E. Relation between body size and bone mineral density in elderly men and women. Am J Epidemiol 1993; 138: 160-9.

5. Meyer HE, Tverdal A, Falch JA. Risk factors for hip fracture in middle-aged Norwegian women and men. Am J Epidemiol 1993; 137: 1203-11.

6. Cummings SR, Nevitt MC, Browner WS, et al. Risk factors for hip fracture in white women. The study of osteoporotic fractures research group. N Engl J Med 1995; 332: 767-73.

7. Hemenway D, Feskanich D, Colditz GA. Body height and hip fracture: a cohort study of 90,000 women. Int $J$ Epidemiol 1995; 24: 783-6.

8. Johnell O, Gullberg B, Kanis JA, et al. Risk factors for hip fracture in European women: the MEDOS Study. Mediterranean Osteoporosis Study. J Bone Miner Res 1995; 10: 1802-15.

9. Statistisk årbok 1994. Oslo: Statistisk sentralbyrå, 1994.

10. O'Neill TW, Felsenberg D, Varlow J, Cooper C, Kanis JA, Silman AJ. The prevalence of vertebral deformity in European men and women: The European vertebral osteoporosis study. J Bone Miner Res 1996; 11:1010-8.

11. Meyer HE, Falch JA, O'Neill T, Tverdal A, Varlow J. Height and body mass index in Oslo, Norway, compared to other regions of Europe: do they explain differences in the incidence of hip fracture? European Vertebral Osteoporosis Study Group. Bone 1995; 17: 347-50.

12. Falch JA, Meyer HE. Lårhalsbrudd - problemer med offisiell helsestatistikk. Tidsskr Nor Lageforen 1996; 116: 3269

13. Falch JA, Kaastad TS, Bøhler G, Espeland J, Sundsvold OJ. Secular increase and geographical differences in hip fracture incidence in Norway. Bone 1993; 14: 643-645. 